Luminos is the Open Access monograph publishing program from UC Press. Luminos provides a framework for preserving and reinvigorating monograph publishing for the future and increases the reach and visibility of important scholarly work. Titles published in the UC Press Luminos model are published with the same high standards for selection, peer review, production, and marketing as those in our traditional program. www.luminosoa.org 

The Social Question in the Twenty-First Century 



\section{The Social Question in the Twenty-First Century \\ A Global View}

Edited by

Jan Breman, Kevan Harris, Ching Kwan Lee, and Marcel van der Linden

뚜

UNIVERSITY OF CALIFORNIA PRESS 
University of California Press, one of the most distinguished university presses in the United States, enriches lives around the world by advancing scholarship in the humanities, social sciences, and natural sciences. Its activities are supported by the UC Press Foundation and by philanthropic contributions from individuals and institutions. For more information, visit www.ucpress.edu.

University of California Press

Oakland, California

(C) 2019 by The Regents of the University of California

This work is licensed under a Creative Commons CC BY-NC-ND license. To view a copy of the license, visit http://creativecommons.org/licenses.

Suggested citation: Breman, J., Harris, K., Lee, C.K., and van der Linden, M. (eds.) The Social Question in the Twenty-First Century: A Global View. Oakland: University of California Press, 2019. DOI: https://doi.org/10.1525/ luminos.74

\section{Library of Congress Cataloging-in-Publication Data}

Names: Breman, Jan, editor. | Harris, Kevan, 1978- editor. | Lee, Ching Kwan, editor. | Linden, Marcel van der, 1952- editor.

Title: The social question in the twenty-first century : a global view / edited by Jan Breman, Kevan Harris, Ching Kwan Lee, and Marcel van der Linden.

Description: Oakland, California : University of California Press, [2019] | Includes bibliographical references and index. | This work is licensed under a Creative Commons CC BY-NC-ND license. To view a copy of the license, visit http://creativecommons.org/licenses. |

Identifiers: LCCN 2019001160 (print) | LCCN 2019005563 (ebook) | ISBN 9780520972483 (ebook) | ISBN 9780520302402 (pbk. : alk. paper)

Subjects: LCSH: Labor-History. | Capitalism-Social aspects. | Equality--Economic aspects.

Classification: LCC HD4855 (ebook) | LCC HD4855.S63 2019 (print) | DDC 306.3--dc23

LC record available at https://lccn.loc.gov/2019001160

$\begin{array}{llllllllll}28 & 27 & 26 & 25 & 24 & 23 & 22 & 21 & 20 & 19\end{array}$

$\begin{array}{llllllllll}10 & 9 & 8 & 7 & 6 & 5 & 4 & 3 & 2 & 1\end{array}$ 


\section{CONTENTS}

List of Illustrations

Preface: The Terrifying Convergence of the

Three Worlds of the "Social Question"

Göran Therborn

1. The Social Question All Over Again

Jan Breman, Kevan Harris, Ching Kwan Lee, and Marcel van der Linden

2. The Social Question in Western Europe: Past and Present

Marcel van der Linden

3. The End of American Exceptionalism: The Social

Question in the United States

Fred Block

4. The Social Question as the Struggle over Precarity:

The Case of China

Ching Kwan Lee

5. Migrants, Mobilizations, and Selective Hegemony in

Mekong Asia’s Special Economic Zones

Dennis Arnold 
6. A Mirage of Welfare: How the Social Question in India Got Aborted Jan Breman

7. The Labor Question and Dependent Capitalism:

The Case of Latin America

Ronaldo Munck

8. Labor and Land Struggles in a Brazilian Steel Town:

The Reorganization of Capital under Neo-Extractivism

Massimiliano Mollona

9. From Poverty to Informality? The Social Question in

Africa in a Historical Perspective

Andreas Eckert

10. The Social Question in South Africa: From Settler Colonialism

to Neoliberal-Era Democracy

Ben Scully

11. The Social Question in the Middle East: Past and Present Kevan Harris

12. Post-Socialist Contradictions: The Social Question in

Central and Eastern Europe and the Making of the Illiberal Right

Don Kalb

13. The Social Question in Russia: From De-Politicization to a

Growing Sense of Exploitation

Karine Clément

14. Postscript: The Social Question in Its Global Incarnation

Jan Breman, Kevan Harris, Ching Kwan Lee, and Marcel van der Linden 


\section{LIST OF ILLUSTRATIONS}

\section{FIGURES}

Figure 5.1. Nominal and real minimum wage of garment and footwear sector, 2000-2015. 82

Figure 11.1. Comparative trends in human development indicators, Middle East and North Africa, 1960-200o. 196

\section{MAPS}

Map 5.1. $\quad$ Mekong Asia. 79

Map 5.2. Thailand's SEZ development. 91 
Dennis Arnold is assistant professor in the Department of Human Geography, Planning, and International Development Studies at the University of Amsterdam.

Fred Block is research professor of sociology at the University of California-Davis.

Jan Breman is emeritus professor of comparartive sociology at the University of Amsterdam.

Karine Clément is associate professor in the Andrew Gagarin Center for Civil Society and Human Rights at the Faculty of Liberal Arts and Sciences at Saint Petersburg State University.

Andreas Eckert is professor of African and Asian studies at Humboldt University.

Kevan Harris is assistant professor of sociology at the University of CaliforniaLos Angeles.

Don Kalb is professor of social anthropology at the University of Bergen.

Ching Kwan Lee is professor of sociology at the University of California-Los Angeles.

Massimiliano Mollona is senior lecturer in the Department of Anthropology at Goldsmiths College in the University of London.

Ronaldo Munck is the head of civic engagement at DCU at Dublin City University and a visiting professor of international development at the University of Liverpool and St. Mary's University, Nova Scotia.

Ben Scully is a senior lecturer in the Department of Sociology at the University of the Witwatersrand.

Göran Therborn is professor emeritus of sociology at the University of Cambridge.

Marcel van der Linden is professor and senior researcher at the International Institute of Social History. 


\title{
Preface
}

\section{The Terrifying Convergence of the Three Worlds \\ of the "Social Question"}

\author{
Göran Therborn
}

Reading this great collection of planet-embracing, penetrating analyses by eminent area specialists, you can almost hear Minerva's owl flapping her wings in the social dusk of the world. We get a picture of how the social issues of the world hang together, with all their differences; we can see how global patterns become discernible, rolled out over time, as well as in space.

Poverty, inequality, and social injustice are ancient plagues of humankind. But they emerged as a "social question" rather late, in a context of the Enlightenment and the Industrial Revolution - the former by putting inequality and human rights on the agenda, though mainly existential inequality before the law, and the latter by producing poverty and misery by wage labor. The editors and authors of this book have put the social question into a broad socioeconomic dynamics of accumulation and dispossession and of class and labor.

The awareness and the notion of a social question derived from the emergence of wage labor-that is, of formally free and substantially unprotected labor, disembedded from family subsistence and constantly at risk from polluting working conditions, from accidents, sickness, unemployment, and from old age frailty. Wage labor emerged and developed on different scales and with different temporalities worldwide, spawning different responses to the question. Industrial wage labor originated in Western Europe, spreading unevenly across the world, most early and successfully to North America, giving rise to what we now call the Global North. Wage labor became the work of the majority of the world's population only recently, in the second decade of the twenty-first century, now estimated by the International Labour Organization (ILO) at 54 percent, up from about 40 percent in the early 1990s. In sub-Saharan Africa and in South Asia, wage labor is still only a fourth of people's work status. 
From a perspective of wage labor in general and of industrial wage labor in particular, there was, as this book shows, a very different trajectory of social development in the Global South, reigning in Africa, Asia, and Latin America, with both intra- and intercontinental variations, just as the northern route comprises the three well-known mini-worlds of welfare capitalism. There are good reasons to distinguish as a third route-also treated in this book-the eastern route of twentieth-century communist socialism, opened by the Russian and the Chinese Revolutions, which provided another approach to the social question. The different areas of wage labor were always connected by the imperialism of European and (later) U.S. capitalism, and area developments were increasingly synchronized by a world time of crucial events, above all, the two World Wars and, decisively, the neoliberal offensive of the 1980 os and onward.

\section{THE GLOBAL ONSLAUGHT OF POSTINDUSTRIAL FINANCE CAPITALISM}

Perhaps the most surprising finding of this rich worldwide overview is the synchronized turn, since the 1980 s, of all the three trajectories of the social question into a neoliberal plunge. With some time lags, there is occurring a dramatic convergence of the three historical paths, toward one of social precarity, of more human exploitation and exclusion-although the legacies of their different employment developments and different social institutions are likely to lead to different responses in the medium term.

In the North, where it all started, there are de-industrialization of employment, beginning in 1965, accelerating from 1975, and the financialization of capitalism, from currency trading, credit deregulation, and the opening up to unhampered international capital movements. These tendencies provided the structural economic underpinnings of aggressive neoliberal ideology and politics.

In the South, weakened by the lure of debt, the neoliberal message spread through the International Monetary Fund-World Bank (IMF-WB) Washington Consensus and its imposition of "structural adjustment policies." A significant role was also played by the military-capitalist economics of Pinochetista Chile, namely, inspiring a worldwide World Bank campaign for privatization of pensions-which ultimately largely failed. In the Arab world, the military-corporatist compact was unraveled, leading up to the Arab Spring, in the end crushed by post-corporatist repression. India experienced how the previous, badly implemented social contract was broken by Hinduist neoliberalism.

In the East, there were the collapse of the Soviet Union and the post-Mao capitalist turn of China. The latter was managed by the Chinese themselves, in many ways very successfully, including a spurt of updated industrialization and a massive lift out of extreme poverty, although with initially brutal social effects-for example, on health care and rural education. The Russian turn was under Western 
tutelage, whose electoral-manipulation experts meddled forcefully in the 1996 Russian election to ensure the victory of the Western candidate. This was the most brutal economic aggression since the heyday of colonial plundering. Between 1990 and 1995, the income share of the bottom half of the Russian population plummeted from 30 percent to 10 percent, and by 2016 , the latter had an income 20 percent below their income in 1989, under communist "stagnation."1

The worldwide commonality of postindustrial neoliberal ideology and ruling practices is highlighted by the current Chinese promotion of "entrepreneurship" and the practice of the gig economy, as Ching Kwan Lee shows in this book. ${ }^{2}$ The worldwide structural changes that made the synchronized global political turn of the 198 os possible still awaits a full-scale analysis.

The chapters of this book provide a somber picture of what the neoliberal onslaught means to the world, and they give us, all of us outside the ever-narrowing circle of the privileged, reasons to fear for our future-but also reasons to fight against our prescribed fate.

The numbers and the proportion of wage workers in the world will continue to grow-as service workers, dispersed among decentralized or small workplaces, never reaching the concentrated mass of big industry workers. The industrial trajectory of the North will not be repeated. Industrial employment seems to have reached its world peak, at barely a fourth of the economically active world population. Deindustrialization has already started in Latin America, and industrial employment has stalled or begun to decline elsewhere. ${ }^{3}$ Even in China, the number of industrial workers seems to have started to decrease in this century. ${ }^{4}$ The northern trajectory of the social question, propelled by industrialization and industrial labor to workers' rights and to social citizenship, is now closed in the South and the East as well as in the North.

\section{FROM THE WORKERS QUESTION TO "INCLUSION"}

The social question of the nineteenth and twentieth centuries was the workers question. The latter is now gone, or discarded, all over the world. Does it have any successor? Perhaps none with any equally broad legitimacy, but in terms of a social issue talked about by a concerned establishment-which was the semantic field of the original social question-there is a plausible candidate. "Inclusion" was put onto the EU agenda of the 2000 Lisbon Strategy, and later adopted by the Organisation for Economic Co-operation and Development (OECD), inserted into the UN Development Goals, and sponsored by the World Bank and the Asian Development Bank in the form of "inclusive growth." The concept does point to something central in postindustrial twenty-first-century societies-the ongoing process of social exclusion and inequality, as evidenced in all of the following chapters.

However, the problem is that the workers question was not really tackled by enlightened ruling-class concern, but by the force of the workers themselves, their 
mutualités, their trade unions, their votes, their strikes and demonstrations, and their political parties, moved forward by the strong tailwind of expansive industrialization. How much force will the excluded and the marginalized of today be able to gather - the shrinking industrial working class, the "informal" workers on sub-industrial-standard employment, the precariat, the subsistence farmers under mounting pressure, the roving day laborers, the street vendors, the neveremployed youth, all facing a strong headwind of global finance capitalism? To what extent will they be able to find allies among the middle-class salariat, also threatened by the ruthlessness of capital accumulation?

And into what kind of society can they be possibly included? Hardly into contemporary capitalism. The industrial response to the workers question was an extensive class compromise, a changed capitalism, of workers' rights and civic rights. Without strong forces of resistance and rebellion, what is awaiting usall rhetoric of "inclusion" notwithstanding-would be galloping inequality and exclusion.

These are questions for a sequel to this great book.

\section{NOTES}

1. F. Alvaredo, L. Chancel, T. Piketty, E. Saez, and G. Zucman, World Inequality Report 2018, 118-19.

2. China cannot be comprehended in one formula, however. The official bicentenary promotion of Marx and the current mandated politburo reading of the Communist Manifesto indicate that.

3. International Labour Organization, World Employment Social Outlook 2018, 30-31.

4. Organisation for Economic Co-operation and Development, Employment Outlook 2017, 122. 